\title{
Acaricidal activity of Amburana cearensis on the cattle tick Rhipicephalus (Boophilus) microplus
}

\author{
Atividade acaricida de Amburana cearensis frente ao Rhipicephalus (Boophilus) microplus
}

\author{
Anne Caroline dos Santos Dantas ${ }^{I}$ Andreina de Carvalho Araujo \\ Alessandra Gomes Marques Pacheco ${ }^{\text {II }}$ Alexsandro Branco ${ }^{\text {II }}$ Luis Antônio Sangioni ${ }^{I I}$ \\ Jackson Roberto Guedes da Silva Almeida ${ }^{I}$ Mauricio Claudio Horta ${ }^{I}$
}

\section{ABSTRACT}

This experiment was carried out to study the bioacaricidal activity of Amburana cearensis against engorged females of Rhipicephalus (Boophilus) microplus. The crude ethanolic extract from the leaves of $\boldsymbol{A}$. cearensis was submitted to partition with organic solvents (hexane, chloroform and ethyl acetate) in order of increasing polarity; and evaluated using three treatments at concentrations of 5,10 and $25 \mathrm{mg} \mathrm{ml}^{-1}$. To evaluate the acaricidal activity, engorged females were submitted to the adult immersion test. Parameters analyzed were the weight of females; weight of egg mass; percentage of hatch; reproductive efficiency; expected rate of reproduction; and efficacy. For each extract and concentrating fraction, tests were performed in triplicate. Among all fractions, the hexane (2.5\%) achieved the best results in all parameters analyzed: $52.7 \%$ of inhibition of oviposition; $39 \%$ of hatching rate; 3,271 index of reproductive efficiency; and $67.0 \%$ effectiveness. The extract obtained gradual dose response with increasing concentration; and could be used as an aid in the control of $\boldsymbol{R}$. (B.) microplus therapy.

Key words: tick, control, acaricid, phytotherapy.

\section{RESUMO}

O objetivo deste estudo foi avaliar a atividade acaricida in vitro de Amburana cearensis contra fêmeas ingurgitadas de Rhipicephalus (Boophilus) microplus. O extrato etanólico bruto das folhas de A. cearensis foi submetido à partição com solventes orgânicos (hexano, clorofórmio e acetato de etila) em ordem crescente de polaridade. Foram realizadas três diluições, nas concentrações de 5, 10 e $25 \mathrm{mg} \mathrm{ml}^{-1}$. Para avaliar a atividade carrapaticida, fêmeas teleóginas foram submetidas ao teste de imersão de fêmeas ingurgitadas. Os parâmetros analisados foram peso das fêmeas, peso da massa de ovos, porcentagem de eclosão, eficiência reprodutiva, índice de reprodução esperada e eficácia. Para cada extrato, fração e concentração, os testes foram realizados em triplicata. Dentre as frações, a hexânica (2,5\%) apresentou os melhores resultados para todos os parâmetros analisados, alcançando 52,7\% de inibição da oviposição; $39,0 \%$ de porcentagem de eclosão; 3.271 de indice de eficiência reprodutiva; e $67 \%$ de eficácia. $O$ extrato obteve uma dose resposta gradual com o aumento da concentração; podendo ser utilizado como terapia auxiliar no controle do $\boldsymbol{R}$. (B.) microplus.

Palavras-chave: carrapato, controle, acaricida, fitoterápico.

\section{INTRODUCTION}

Popularly known as "cattle tick", Rhipicephalus (Boophilus) microplus, in addition to being one of the most important vectors of pathogens to the cattle (DE CASTRO, 1997), is responsible for major losses of livestock sector (GEORGE et al., 2002). The control of this tick is usually done with conventional synthetic chemicals which present problems in the accelerated development of resistance to the active principle (LEAL, 2003). Typically, once resistance is established, the producer increases drug dose or frequency of application (THULLNER, 1997). The intensive use of these chemicals has led to contamination of the environment, exposure of rural workers and the presence of chemical residues in milk and meat, which caused concern in society and government agencies (LEAL et al., 2003).

\footnotetext{
IUniversidade Federal do Vale do São Francisco (UNIVASF), Petrolina, PE, Brasil.

"Laboratório de Fitoquímica, Universidade Estadual de Feira de Santana (UEFS), Feira de Santana, BA, Brasil. Maria, RS, Brasil. E-mail: lasangioni@gmail.com. Corresponding author.

IIIDepartamento de Medicina Veterinária Preventiva, Universidade Federal de Santa Maria (UFSM), Av. Roraima, 1000, 97105-900, Santa 
Due to the many difficulties in controlling and combating this arthropod, the use of medicinal plants is an increasingly viable alternative in developing countries such as Brazil, mainly due to the great variability of species, low cost, easy availability, fast degradation when compared to chemicals and, consequently, reducing contamination of the environment, animals and men (OLIVO et al., 2008), these being the main reasons for the study of plants which have true acaricide effects (DANTAS et al., 2015).

Amburana cearensis (Fabaceae) popularly known as "cumaru" or "imburana-decheiro", is a tree of economic importance, typical of northeastern backwoods, which is widely used for carpentry, perfumery and pharmaceutical purposes (MAIA, 2004). The stem bark, indicated for the treatment of respiratory diseases, is widely used in folk medicine to prepare a home formulation and also in the industrial production of herbal "cumaru syrup" (LEAL et al., 1997).

This research aimed to evaluate the acaricidal activity in vitro of the leaves from the $\boldsymbol{A}$. cearensis on the cattle tick $\boldsymbol{R}$. (B.) microplus, using engorged adult immersion tests.

\section{MATERIALS AND METHODS}

The leaves of Amburana cearensis were collected in the municipality of Petrolina, state of Pernambuco, Brazil, in September of 2011. Samples were identified by a botanist and a voucher specimen (5545) was deposited at the Herbarium Vale do São Francisco (HVASF) of the Federal University of São Francisco Valley.

Leaves dried and pulverized were macerated with ethanol $95 \%$ at room temperature for $72 \mathrm{~h}$. The solution was filtered and concentrated under reduced pressure in a rotary evaporator at $50^{\circ} \mathrm{C}$; producing $30 \mathrm{~g}$ of crude ethanolic extract (Ac-EtOH). Fractions were obtained using a sequence of solvents of increasing polarity: hexane (Ac-HEX), chloroform $\left(\mathrm{Ac}-\mathrm{CHCl}_{3}\right)$ and ethyl acetate (Ac-AcOEt); after extraction the solutions were decanted, filtered and the solvents removed by evaporation under reduced pressure.

Analysis of phenolic compounds profile were performed by high performance liquid chromatography (HPLC) using a liquid chromatograph (Hitachi model Lachrom Elite), column LiCospher 100 RP18 (5mm) with dimensions (150mm x04mm) (Merck), equipped with Diode Array Detector (DAD). The mobile phase used was a solution of $\mathrm{H}_{2} \mathrm{O} / \mathrm{H}_{3} \mathrm{PO}_{4} 0.1 \%$ (A) and $\mathrm{MeOH}$ (B) provided initial $75 \%$ of $\mathrm{A}$ and $25 \%$ of $\mathrm{B}$ for 25 minutes. The column temperature was kept constant at $30^{\circ} \mathrm{C}$ with a flow of $1.0 \mathrm{ml} / \mathrm{min}$, using an injection volume of $20 \mu \mathrm{l}$ for each extract. Spectral data were recorded in $220 \mathrm{~nm}$ during the whole run.

Engorged females of $\boldsymbol{R}$. (B.) microplus (among 4 and $8 \mathrm{~mm}$ ) were collected from a naturally infested herd from the municipality of Petrolina; kept off of the farms, and free of chemical insecticide. They were placed in plastic containers with adequate aeration and taken to the laboratory in cooler containing ice, to reduce the mobility and prevent premature oviposition of female (BROGLIOMICHELLETI et al., 2009). These females were incubated at $27-28^{\circ} \mathrm{C}$ and $70-80 \%$ relative humidity for two weeks until the eggs were laid. After hatching, two cows were artificially infested with the larvae, to ensure that these ticks were free of chemicals. $\boldsymbol{R}$. (B.) microplus females in the later stages of engorgement were collected from infested animals, washed with water and dried in paper toweling. Females were used in the adult engorged test immersion (DRUMMOND et al., 1973). Ticks were washed in running water, dried with paper towels and selected by size in groups of homogeneous treatments for the appearance, mobility, physical and engorgement (ARANTES et. al., 1995). They were divided into groups of 10 ticks per treatment, with tests carried out in triplicate.

The groups were weighed on analytical balance and submitted to immersion bath for five minutes in $20 \mathrm{~mL}$ solution the extracts diluted to concentrations of 5,10 and $25 \mathrm{mg} \mathrm{ml}^{-1}$. In the control group, the immersion liquid used was distilled water and, when necessary, the control was held with cremophor surfactant. After the immersion, the ticks were dried with paper towels, placed in sterile Petri dishes and incubated at $27-28^{\circ} \mathrm{C}, 70-80 \%$ relative humidity. After 14 days, the number of eggs per female were collected, then weighed and observed. Eggs were placed in glass tubes, incubated at the same conditions and after 14 days the tubes were observed and the hatching rates of the different treatments were estimated with the aid magnifying glass and compared to the controls.

The parameters were calculated as follows: Percentage inhibition of oviposition $(\% \mathrm{IO})=[\mathrm{IO}$ (control)- IO (treated)/IO (control)] x100; Reproductive efficiency $(\% \mathrm{RE})=[(\mathrm{EW}) \times(\% \mathrm{E} \times 0,01) /(\mathrm{IFW})] \mathrm{x}$ 20,000; Efficacy $\left.(\% \mathrm{EF})=\left[\mathrm{EF}_{\text {(control) }}-\mathrm{EF}_{\text {(treated }}\right) / \mathrm{EF}_{\text {(control) }}\right]$ $\mathrm{x} 100$; where: $\mathrm{IO}=$ inhibition of oviposition; $\mathrm{RE}=$ reproductive efficiency; IFW = initial female weight; $\mathrm{EW}=$ egg weight, $\mathrm{E}=$ hatching rate; and $\mathrm{EF}=$ efficacy.

The data obtained were analyzed using the GraphPad Prism program version 5.0 and expressed 
as mean \pm S.E.M. Statistically significant differences between groups were calculated by the application of analysis of variance (ANOVA) followed by Tukey test and confirming with Student t-test. Values were considered significantly different at $\mathrm{P}<0.05$.

\section{RESULTS AND DISCUSSION}

The profile of phenolic compounds of the crude ethanolic extract, as well as for the phases obtaining for partition is shown in figure 1 . According to retention time and absorption bands in the ultraviolet spectra obtained by HPLC-DAD, the compounds present in the ethanolic extract are characteristic of of benzoic acid and cinamic acid derivatives, and flavonoids. Studies carried out using co-injection with standards, revealed the presence of protocatechuic acid, epicatequin, $p$-coumaric acid, galic acid and kaempferol as major constituents of Ac-EtOH (GOUVEIA et al., 2015). Flavonoid derivatives were indentified in hexane, chloroform and ethyl acetate extracts.
Results for initial weight of female (IFW), egg weigh (EW), percentage inhibition oviposition $(\% \mathrm{IO})$, hatching rate $(\% \mathrm{E})$, reproductive efficiency ( $\% \mathrm{RE}$ ) and efficacy ( $\% \mathrm{EF})$; of the leaves of $\boldsymbol{A}$. cearensis were demonstrated in table 1 . There was no statistical difference for the weight of $\mathrm{t}$ female and egg weight.

The hexane extract (Ac-HEX) showed inhibition of the oviposition at all concentrations (5, 10 and $25 \mathrm{mg} \mathrm{mL}^{-1}$ ), showing $\% \mathrm{IO}$ of $13.2 \%, 20.8 \%$ and $52.7 \%$, respectively. In the same concentrations, the group treated with chloroform extract $\left(\mathrm{Ac}-\mathrm{CHCl}_{3}\right)$ showed $\%$ IO of $5.3 \%, 24.1 \%$ and $28.1 \%$ respectively. The group treated with ethyl acetate extract (AcAcOEt) obtained percentage of $6.8 \%, 13.8 \%$ and $11.8 \%$, while the treated group with Ac-EtOH obtained $8.5 \%, 6.9 \%$ and $31.9 \%$, at concentrations of 5,10 and $25 \mathrm{mg} \mathrm{mL}^{-1}$. There was no significant difference in any of phases.

Ac-HEX showed the best result of hatching rate at concentrations of $25 \mathrm{mg} \mathrm{mL}^{-1}(39 \%)$, followed by $81.7 \%$ and $76.3 \%$ at concentrations of 5 and $10 \mathrm{mg} / \mathrm{mL}$, respectively. For Ac- $\mathrm{CHCl}_{3}$, hatching of

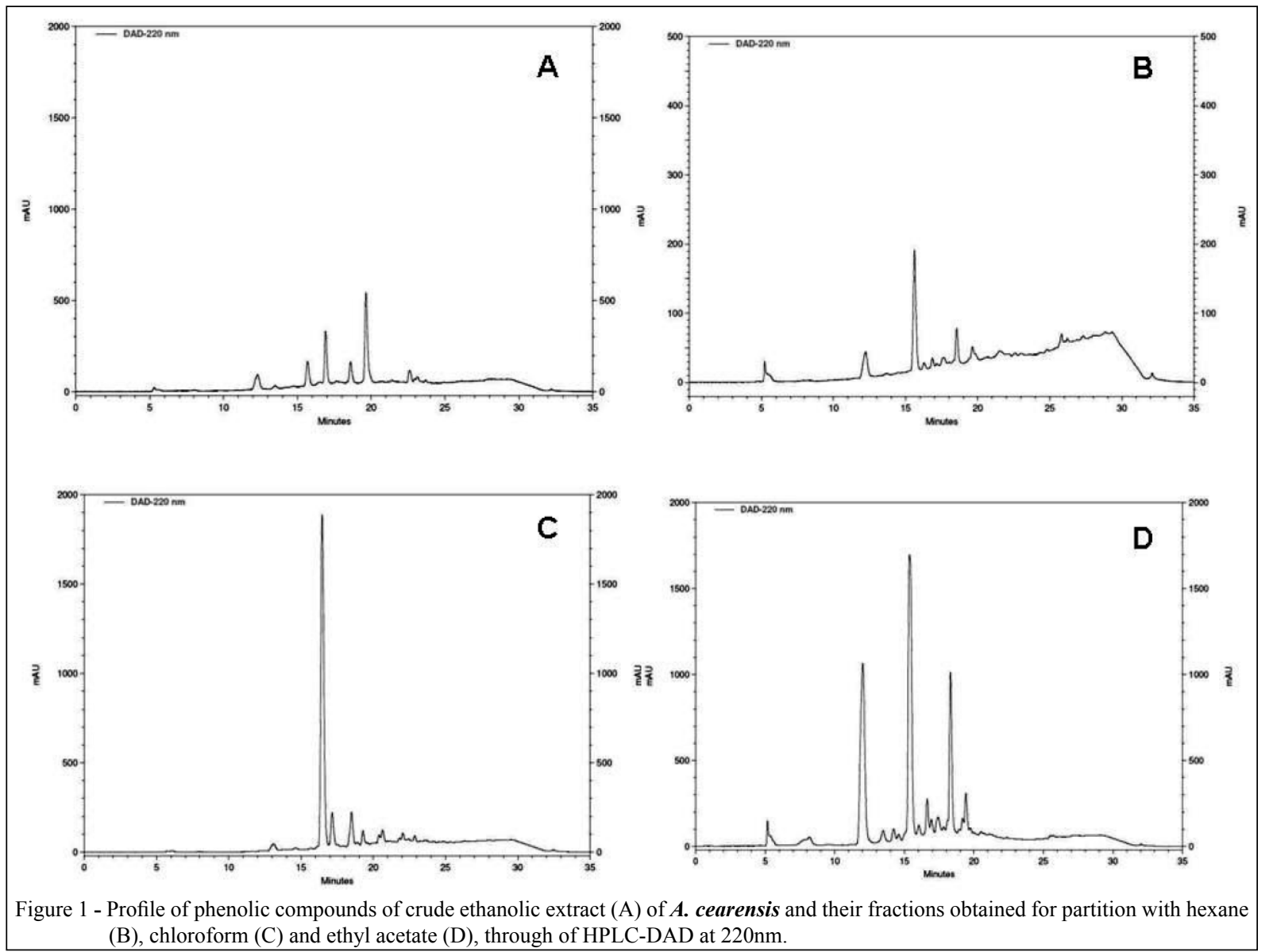

Ciência Rural, v.46, n.3, mar, 2016. 
Table 1 - Evaluation of the effectiveness of the engorged females Rhipicephalus (Boophilus) microplus ticks in adult immersion test in different extract from the leaves of Amburana cearensis.

\begin{tabular}{|c|c|c|c|c|c|c|}
\hline Extract $(\mathrm{mg} / \mathrm{mL})$ & $\begin{array}{c}\text { Initial female } \\
\text { weight - IFW (g) }\end{array}$ & $\begin{array}{c}\text { Egg weight }- \text { EW } \\
(\mathrm{g})\end{array}$ & $\begin{array}{c}\text { Inhibition } \\
\text { oviposition - IO } \\
(\%)\end{array}$ & Hatching - H (\%) & $\begin{array}{c}\text { Reproductive } \\
\text { efficiency - RE } \\
\text { (eggs ) }\end{array}$ & Efficacy - EF (\%) \\
\hline \\
\hline 5 & $0.17 \pm 0.01$ & $0.07 \pm 0.007$ & $13.25 \pm 8.15$ & $81.67 \pm 12.39$ & $7664 \pm 1435$ & $22.67 \pm 13.91$ \\
\hline 10 & $0.15 \pm 0.02$ & $0.06 \pm 0.01$ & $20.83 \pm 15.81$ & $76.33 \pm 21.22$ & $6594 \pm 2231$ & $34.76 \pm 21.94$ \\
\hline 25 & $0.16 \pm 0.01$ & $0.04 \pm 0.03$ & $52.73 \pm 41.39$ & $39.00 \pm 38.74$ & $3271 \pm 3783$ & $66.88 \pm 38.56$ \\
\hline 5 & $0.19 \pm 0.02$ & $0.09 \pm 0.02$ & $\begin{array}{l}\text { Chloroform---- } \\
5.26 \pm 7.20\end{array}$ & $94.67 \pm 1.52$ & $8864 \pm 745,1$ & $6.50 \pm 6.67$ \\
\hline 10 & $0.17 \pm 0.02$ & $0.06 \pm 0.01$ & $24.10 \pm 9.48$ & $91.27 \pm 0.87$ & $6838 \pm 895,2$ & $27.5 \pm 12.44$ \\
\hline 25 & $0.16 \pm 0.04$ & $0.05 \pm 0.006$ & $28.04 \pm 9.60$ & $75.83 \pm 7.28$ & $6235 \pm 984$ & $35.78 \pm 4.51$ \\
\hline 5 & $0.17 \pm 0.03$ & $0.08 \pm 0.01$ & $\begin{array}{c}\text {-Ethyl acetate--- } \\
6.84 \pm 13.85\end{array}$ & $83.00 \pm 22.61$ & $7999 \pm 2310$ & $20.21 \pm 23.86$ \\
\hline 10 & $0.16 \pm 0.02$ & $0.07 \pm 0.02$ & $13.85 \pm 15.90$ & $82.83 \pm 8.78$ & $7257 \pm 1851$ & $27.66 \pm 18.98$ \\
\hline 25 & $0.17 \pm 0.02$ & $0.07 \pm 0.02$ & $11.79 \pm 13.82$ & $58.67 \pm 18.61$ & $5621 \pm 2074$ & $43.98 \pm 20.85$ \\
\hline 5 & $0.17 \pm 0.007$ & $0.07 \pm 0.009$ & $\begin{array}{l}-- \text { Ethanol---- } \\
8.49 \pm 10.92\end{array}$ & $84.67 \pm 16.65$ & $8021 \pm 2187$ & $20 \pm 22.58$ \\
\hline 10 & $0.17 \pm 0.002$ & $0.07 \pm 0.009$ & $6.91 \pm 10.28$ & $83.67 \pm 7.76$ & $7753 \pm 1555$ & $21.78 \pm 15.05$ \\
\hline 25 & $0.18 \pm 0.01$ & $0.06 \pm 0.02$ & $31.91 \pm 28.02$ & $52.00 \pm 25.24$ & $4910 \pm 2637$ & $52.03 \pm 23.36$ \\
\hline $\begin{array}{l}\text { Control } 1 . \\
\text { Distilled water }\end{array}$ & $0.21 \pm 0.01$ & $0.10 \pm 0.005$ & & $99 \pm 1.73$ & $10050 \pm 139.1$ & \\
\hline $\begin{array}{l}\text { Control } 2 . \\
\text { Distilled water } \\
\text { with cremophor }\end{array}$ & $0.20 \pm 0.04$ & $0.09 \pm 0.02$ & & $98 \pm 3.46$ & $10089 \pm 458.6$ & \\
\hline
\end{tabular}

$94.7 \%, 91.3 \%$ and $75.8 \%$ was observed, and, in AcAcOEt the hatching was $83.0 \%, 82.8 \%$ and $58.7 \%$, respectively. Ac-EtOH showed inhibition of $52.0 \%$ for the high concentration; and $84.7 \%$ and $83.7 \%$ at the concentrations 5 and $10 \mathrm{mg} \mathrm{mL}^{-1}$, respectively.

A. cearensis was able to inhibit in all stages reproductive efficiency of engorged females, is more evident effect on Ac-HEX, showed 7664, 6594 and 3271 , for the concentrations of 5,10 and $25 \mathrm{mg}$ $\mathrm{mL}^{-1}$, respectively. $\mathrm{Ac}-\mathrm{CHCl}_{3}$ at same concentrations, showed less effects with 8864, 6838 and 6235. The group treated with Ac-AcOEt did not show significant inhibition in reproductive efficiency, presenting the best effect on concentration $25 \mathrm{mg} \mathrm{mL}^{-1}$ with inhibition of 5621 and the treated groups with Ac-EtOH showed an estimated reproduction of 8021 for concentration $0.5 \%$ and 4910 for concentration $25 \mathrm{mg} \mathrm{ml}^{-1}$.

Through the immersion of engorged females test, it was possible to determine the acaricidal activity of $\boldsymbol{A}$. cearensis. Ac-HEX showed efficacy of $66.9 \%$ for the concentration at $25 \mathrm{mg} \mathrm{ml}^{-1}$; followed by 34.8 and $22.7 \%$ at 5 and $10 \mathrm{mg} \mathrm{ml}^{-1}$, respectively. For Ac-EtOH a gradual reduction was shown in the efficiency, obtaining $52.0 \%, 21.8 \%$ and $20.0 \%$ for the same concentrations described above. The minor efficiencies have been obtained by Ac-AcOEt and Ac-
$\mathrm{CHCl}_{3}$, at concentrations of 5, 10 and $25 \mathrm{mg} \mathrm{mL}^{-1}$, their efficacy $20.2 \%, 27.7 \%$ and $44.0 \%$ and $6.5 \%, 27.5 \%$ and $35.8 \%$, respectively.

The chemical composition of $\boldsymbol{A}$. cearensis is basically composed of coumarin, responsible for its peculiar flavour, and also of flavonoids isokampferideo, kaempferol and afrormosin (BRAVO et al., 1999). Studies have revealed that the coumarin, isokampferideo and amburosidio A, had anti-inflammatory, antioxidant and bronchodilator effects, indicating the active plant principles (LEAL et al., 2003). In order to locate the active ingredients with acaricide action, the crude extracts of the plants were partitioned (CECHINEL \& YUNES, 1998) and evaluated using the immersion test of engorged females. This test was used to detect the resistance of the acaricidal, and in recent yearswas widely used to evaluate the herb efficacy .

In immersion tests, leaves of $\boldsymbol{A}$. cearensis, showed $66.7 \%$ efficacy for the hexane extract $\left(25 \mathrm{mg} \mathrm{ml}^{-1}\right)$. This fraction was responsible for the best results plant in all parameters. A. cearensis showed no direct mortality on engorged females in any of its fractions, but the hexane extract reduced the oviposition (52.7\%) and especially the eggs hatching $(39.0 \%)$, with partial acaricide effect on

Ciência Rural, v.46, n.3, mar, 2016. 
female fertility. Similar results were obtained for MONTEIRO et al. (2010) researching the effect of thymol monoterpene on engorged females of $\boldsymbol{R}$. (B.) microplus, where they observed that the percentage of hatching was lower than the values of the controls. However, when the eggs were treated directly, thymol $2 \%$ did not significantly affect this parameter. Thus, it can be inferred that thymol did not have a direct deleterious action in the incubation of eggs.

The diluent used in the solubilization extract has significant importance since it enhance the effectiveness of the extract or not (PIVOTO et al., 2010). The low molecular weight and low viscosity solvents are preferred for immersion tests (CHAGAS et al., 2012). In this study, water was used as a diluent, and to the insoluble substances in water was added the surfactant Cremophor. There are no data in the literature that report the effect of cremophor on engorged females $\boldsymbol{R}$. (B.) microplus. There was no significant difference between the control group 1 (water) and 2 control (water and cremophor), in this study.

A. cearensis showed higher acaricide activity in hexane extract. These results were similar to the study of ROSADO-AGUILAR et al. (2010), that the crude extract generated partitions in order to evaluate the metabolic profile of Petiveria alliacea. Hexane fraction of $\boldsymbol{P}$. alliacea obtained more effective results against the larvae of $\boldsymbol{R}$. (B.) microplus. Taking into account the use of solvents of increasing polarity during column chromatography, we found that the action insecticide was among the non-polar compounds of plant. In the non-polar extract, substances such as steroids, terpenes, acetophenones, aglycone, waxes, sapogenins, iridoids and sesquiterpenes, highly lipophilic substances can be found (CECHINEL \& YUNES, 1998; CANTRELL et al., 2001). Terpenes are reported to have acaricidal effects and are, therefore, the object of several studies. This class of metabolites covers a wide range of substances of vegetable origin and their ecological importance as defensive is well established. Several monoterpenes were isolated and evaluated for toxicity against different insects and arthropods (VIEGAS JUNIOR, 2003). Our results demonstrate the potential acaricidal activity of $\boldsymbol{A}$. cearensis, which contributes to the conservation and proper management of this species, since, beyond economic potential; they are likely to be exploited as sources of new biologically active substances.

\section{CONCLUSION}

The crude ethanolic extract and fractions of A. cearensis has demonstrated inhibitory action in the development of eggs, suggesting that they are good candidates for the development of new acaricidal agents. The hexane extract showed higher results, suggesting that the acaricide activity comes from molecules with nonpolar characteristics. Additional studies should be conducted to identify the active compounds and their effects on other life stages of the tick.

\section{BIOETHICS AND BIOSSECURITY COMMITTE APPROVAL}

Committee of Ethics and Deontology Studies and Research at the Universidade Federal do Vale do São Francisco (UNIVASF), protocol number 10072012.

\section{REFERENCES}

ARANTES, G.J. et al. The cattle tick, Boophilus microplus, in the municipality of Uberlândia, MG: analysis of resistance against commercial products. Revista Brasileira de Parasitologia Veterinária, v.4, n.2, p.89-93, 1995. Available from: <http://www.cbpv.org.br/rbpv/ documentos/421995/c4289 93.pdf>. Accessed: Aug. 31, 2015.

BRAVO, J.A. et. al. Bioactive phenolic glycosides from Amburana cearensis. Phytochemistry, v.50, p.71-74, 1999. Available from: $<\mathrm{http}: / / \mathrm{www}$. sciencedirect.com/science/article/pii/ S003194229800497X>. Accessed: Dec. 17, 2013. doi: 10.1016/ S0031-9422(98)00497-X

BROGLIO-MICHELETTI, S.M.F. et al. Plant extracts in control of Rhipicephalus (Boophilus) microplus (Canestrini, 1887) (Acari: Ixodidae) in laboratory. Revista Brasileira de Parasitologia Veterinária, v.18, n.4, p.44-48, 2009. Available from: <http:// www.scielo.br/pdf/rbpv/v18n4/a08v18>. Accessed: Oct. 22, 2012. doi: $10.4322 /$ rbpv.0180400.

CECHINEL, F.V.; YUNES, R.A. Concepts about structural modification for improve the activity. Química Nova, v.21, n.1, p.99-105, 1998. Available from: <http://www.scielo.br/pdf/qn/ v21n1/3475>. Accessed: Dec. 08, 2013. doi: 10.1590/S010040421998000100015

CHAGAS, A.C.S. et. al. In vitro efficacy of plant extracts and synthesized substances on Rhipicephalus (Boophilus) microplus (Acari: Ixodidae). Parasitology Research, v.110, p.295-303, 2012. Available from: <http://link.springer.com/ article/10.1007\%2Fs00436-011-2488-z>. Accessed: Feb. 22, 2013. doi: 10.1007/s00436-011-2488-z.

CANTRELL, C.L. et. al. Antimycobacterial plant terpenoids Planta Medicinal, v.67, n.1, p.1-10,2001. Available from: $<$ https:// www.thieme-connect.com/DOI/DOI?10.1055/s-2001-18365>. Accessed: Feb. 18, 2013. doi: 1055/s-2001-18365.

DANTAS, A.C.S. et al. Acaricidal activity of extracts from the leaves and aerial parts of Neoglaziovia variegata (Bromeliaceae) on the cattle tick Rhipicephalus (Boophilus) microplus. Research in Veterinary Science, v.100, p.165-168, 2015. Available from: $<$ http://www.sciencedirect.com/science/article/pii/ S0034528815001198>.

DE CASTRO, J. Sustainable tick and tick- borne disease control in livestock improvement in developing countries. Veterinary 
Parasitology, v.71, n.2-3, p.77-97, 1997. Available from: <http:// www.sciencedirect.com/science/article/pii/S0304401797000332>. Accessed: Mar. 02, 2013. doi: 10.1016/S0304-4017(97)00033-2.

DRUMMOND, R.O. et. al. Boophilus annulatus and Boophilus microplus: laboratory tests of insecticides. Journal of Economic Entomology, v.66, p.130-133, 1973.

GEORGE, S.E. et al. Introduced ticks and tick-borne diseases: the threat and approaches to eradication. Veterinary Clinics of North America: Food Animal, v.18, n.3, p.401-416, 2002.

GOUVEIA, B.B. et. al. Effect of ovarian tissue transportation in Amburana cearensis extract on the morphology and apoptosis of goat preantral follicles. Animal Reproduction, v.12, p.316-323 2015. Available from: $<$ http://www.cbra.org.br/pages/publicacoes/ animalreproduction/issues/download/v12/v12n2/p316-323\%20 \%28AR658\%29.pdf>. Accessed: Jul. 09, 2015.

LEAL, A.T. et al. Perspectives for control of bovine tick. Acta Scientia e Veterinariae, v.31, n.1, p.1-11, 2003. Available from: $<$ http://www.lume.ufrgs.br/handle/10183/19793>. Accessed: Mar. 03, 2013. doi: hdl.handle.net/10183/19793.

LEAL, I.R. et al. Ecologia e conservação da caatinga. Recife: UFPE, 2003. 822p.

LEAL, L.K.A.M. et. al. Antinociceptive and antiedematogenic effects of the hydroalcoholic extract and coumarin from Torresea cearensis Fr. All. Phytomedicine, v.4, p.221, 1997. Available from: <http:// www.sciencedirect.com/science/article/pii/S0944711397800712>. Accessed: Mar. 11, 2013. doi: 10.1016/S0944-7113(97)80071-2.

LEAL, L.K.A.M. et al. Anti-inflammatory and smooth Muscle relaxant activities of the hydroalcoholic extract and chemical constituents from Amburana cearensis A C Smith. Phytotherapy Research, v.17, p.335-340, 2003. Available from: <http:// onlinelibrary.wiley.com/doi/10.1002/ptr.1139/pdf $>$. Accessed: Mar. 11, 2013. doi: 10.1002/ptr.1139.
MAIA, G.N. Caatinga: árvores e arbustos e suas utilidades. São Paulo: D \& Z Editora, 2004. p.33-34. 100p.

MONTEIRO, C.M.O. et. al. Acaricide and ovicide activities of thymol on engorged females and eggs of Rhipicephalus (Boophilus) microplus (Acari: Ixodidae). Parasitology Research, v.106, p.615-619, 2010. Available from: <http://link. springer.com/article/10.1007\%2Fs00436-009-1709-1>. Accessed: Mar. 11, 2013. doi: 10.1007/s00436-009-1709-1.

OLIVO, C.J. et al. Citronella oil on the control of cattle ticks. Ciência Rural, v.38, p.406-410, 2008. Available from: <http://www.scielo.br/pdf/cr/v38n2/a18v38n2.pdf>. Accessed: Jul. 09, 2015.

PIVOTO, F.L. et al. In vitro acaricidal effect of Tropaeolum majus on the engorged female of Rhipicephalus (Boophilus) microplus. Ciência Rural, v.40, n.10, p.2141-2145, 2010. Available from: $<$ http://www.scielo.br/pdf/cr/2010nahead/a749cr3510.pdf $>$. Accessed: Mar. 15, 2013.

ROSADO-AGUILAR, J.A. et al. Acaricidal activity of extracts from Petiveria alliacea (Phytolaccaceae) against the cattle tick, Rhipicephalus (Boophilus) microplus (Acari: ixodidae). Veterinary Parasitology, v.168, p.299-303, 2010. Available from: <http:/www.sciencedirect.com/science/article/ pii/S0304401709007006>. Accessed: Mar. 15, 2013. doi: 10.1016/j.vetpar.2009.11.022.

THULLNER, F. Impact of pesticide resistance and network for global pesticide resistance management based on a regional structure. World Animal Review RMZ, v.89, p.41-47, 1997.

VIEGAS JUNIOR, C. Terpenes with insecticidal activity: an alternative to chemical control of insects. Química Nova, v.26, p.390-400, 2003. Available from: <http://www.scielo. br/scielo.php?pid=S0100-40422003000300017\&script $=$ sci arttext $>$. Accessed: Mar. 18, 2013. doi: 10.1590/S010040422003000300017 . 